
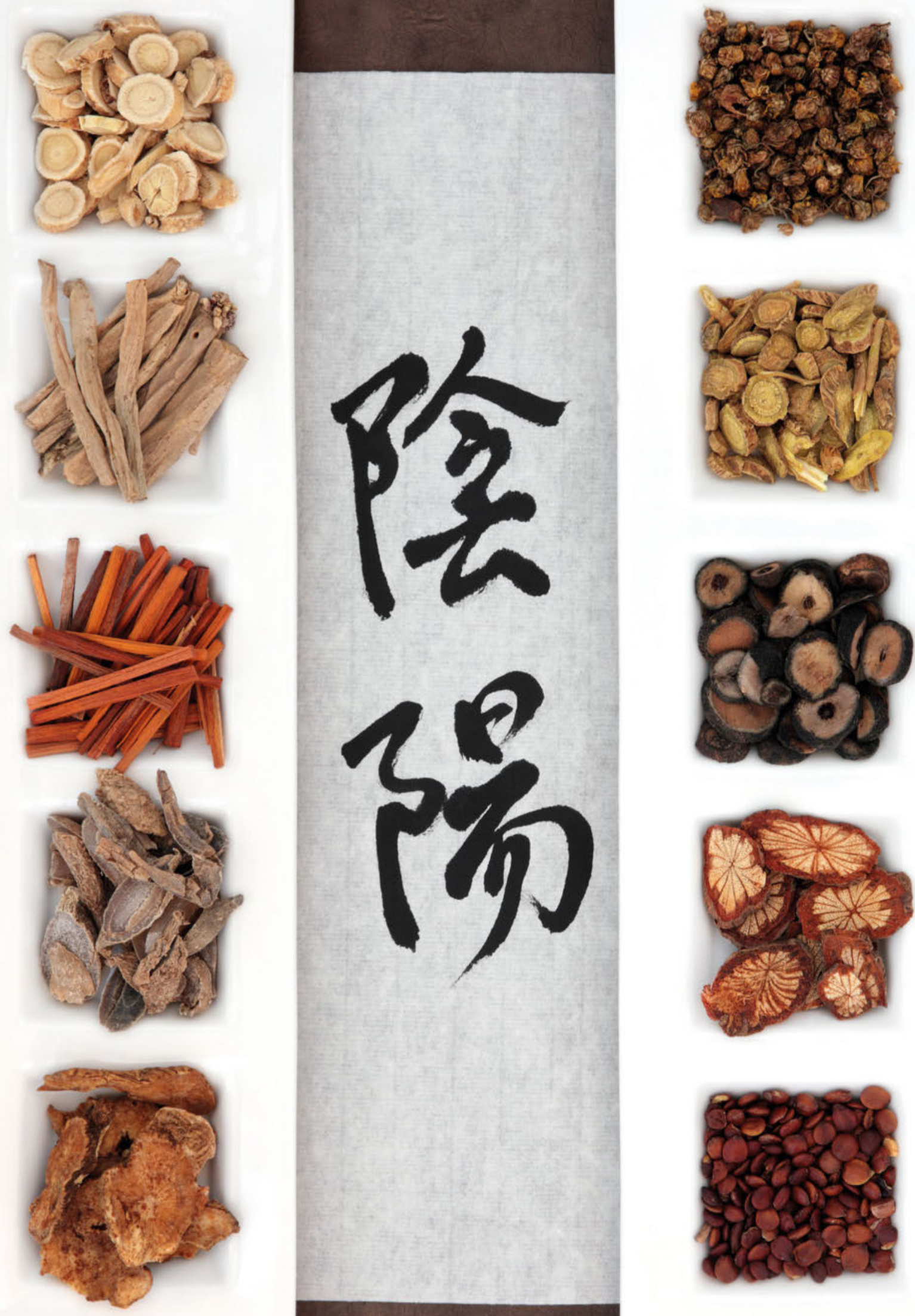


\title{
Chinesische \\ Arzneimitteltherapie als mögliche Alternative zur Antibiotikatherapie
}

\author{
Antibakterielle, antivirale und antiinflammatorische Bestandteile chinesischer Arzneidrogen \\ können Behandlungsalternative bei bakteriellen Infekten sein - Zusätzliche Gabe chinesischer \\ Arzneidrogen zu Antibiotika kann bakterielle Sensibilität wiederherstellen \\ Josef Hummelsberger
}

\section{Einführung}

Das Problem der multiresistenten Bakterien (Bsp. MRSA) wird sowohl von der WHO als auch der EU weltweit als Bedrohung der öffentlichen Gesundheit betrachtet. Beide Institutionen fordern schnelle Maßnahmen, um die Antibiotikaresistenzen zu bekämpfen. Es geht sowohl um die Entwicklung neuer Antibiotika als auch um die Entwicklung alternativer Behandlungsoptionen, auch im Bereich der komplementären und alternativen Medizin (CAM) [1].

Ein besonders für dieses Thema wichtiger CAM-Bereich sind die Phytotherapeutika. Aufgrund der Biodiversität Chinas, ca. $12 \%$ aller weltweit bekannten Pflanzenarten sind in China beheimatet, und dem daraus resultierenden hohen Anteil arzneilich nutzbarer Arten (ca. 700 offizielle Einträge in der Pharmakopoe Chinas [2]), der induk- tiv-empirischen Systematik der (traditionellen) chinesischen Medizin [3, 4] und des trotz aller Zeitläufe - bewahrten traditionellen Medizinwissens ist die Chinesische Arzneitherapie (CAT) eine besondere Chance.

Aktuell hat die CAT in China wieder an Ansehen gewonnen, da sie während der SARS-Epidemie und anderen viralen Infekten als besonders wirksam erfahren wurde und intensiv gefördert und beforscht wird.

Die Chinesische Arzneimitteltherapie wurde - anders als bei uns immer geglaubt - bei akuten Krankheiten und besonders bei Infekten eingesetzt [5]. Wichtige Werke und Traditionen wie das Shanghanlun (Diskussion über „Kälte“-Krankheiten) und das Wenbingxue (Lehre von den „Wärme“Krankheiten) beschreiben detailliert den Ablauf von Erkältungen und Infektionen

\section{Zusammenfassung}

Phytotherapeutika bieten großes Potenzial zur Lösung des Problems multiresistenter Keime beizutragen. Die Chinesische Arzneimitteltherapie hat u. a. während der SARS-Epidemie wieder an Ansehen gewonnen, da sie als besonders wirksam erfahren wurde und intensiv erforscht wird. Aufgrund der Biodiversität Chinas existieren zahlreiche arzneilich nutzbare Arten. Die Chinesische Arzneimitteltherapie nutzt nicht nur einen Bestandteil, sondern auch Kombinationen von 2 bis zu 15 Pflanzen, um die Wirksamkeit durch Synergismen zu verstärken und Nebeneffekte zu reduzieren.

Der Beitrag stellt bewährte Rezepturen vor für häufig auftretende bakterielle Infekte sowie wichtige Studienergebnisse zu MRSA, Helicobacter pylori, Salmonellen und Harnwegsinfekten.

und entwickeln spezifische Strategien und Therapien. Es existiert eine ungeheure Anzahl von chinesischen Arzneidrogen mit antibiotischen bzw. antiviralen Effekten.

\section{Chinesische Arzneimitteltherapie}

Die CAT wird häufig als traditionelle Chinesische Phytotherapie bezeichnet. Neben der Verwendung von Pflanzensamen, Beeren, Wurzeln, Blättern, Rinden oder Blüten werden in Einzelfällen aber auch Arzneidrogen mineralischen und tierischen Ursprungs genutzt.

Die Arzneimittel der CAT enthalten zahlreiche chemische Konstituenten, die in der Krankheitsbehandlung synergistisch zusammenarbeiten. Die CAT nutzt, wie andere traditionelle phytotherapeutische Systeme (Ayurveda, Traditionelle Europäische Medizin etc.), nicht nur einen Bestandteil, sondern darüber hinaus Zusammenstellungen von 2 bis zu 15 Pflanzen, um die Wirksamkeit durch Synergismen zu verstärken, Nebeneffekte zu reduzieren und zusätzliche Symptome (z.B. Husten bei Bronchitis) mit zu behandeln. Auch in der westlichen Phytotherapie findet eine Rückbesinnung auf Synergismen und Verwendung ganzer Pflanzen und nicht einzelner Bestandteile $\operatorname{statt}$ (z.B. Iberogast oder Kompositionen mit Johanniskraut). 


\section{Mod. „Gentiana-Dekokt zur Zer- streuung des Funktionskreis Leber“ (jia longdan xiegan tang)}

- Gentiana longdancao radix (longdancao) $12 \mathrm{~g}$

- Scutellariae radix (huangqin) $12 \mathrm{~g}$

- Gardeniae fructus (zhizi) $9 \mathrm{~g}$

- Rhemania viride radix (shengdi) $15-45 \mathrm{~g}$ (!)

- Bupleuri radix (chaihu) $9 \mathrm{~g}$

- Alisematis rhizoma (zexie) $9 \mathrm{~g}$

- Plantaginis semen (cheqianzi) $15 \mathrm{~g}$

- Clematis caulis (chuanmutong) $6 \mathrm{~g}$

- Angelica sinensis radix (danggui) $9 \mathrm{~g}$

- Glycyrrhizae radix (gancao) 6g

- Saphosnikoviae radix (fangfeng) $9 \mathrm{~g}$

(Angaben g Tagesdosis/Rohdroge, zusam-

men 30 min abgekocht und dann warm in

3 Dosen über den Tag verteilt eingenommen)

- Forsythiae fructus (lianqiao)

- Hediotydis herba (baihua sheshe cao)

- Taraxaci herba (pugongying)

Zu Andrographis paniculata (chuanlinxian, AP) liegt eine aktuelle Metanalyse vor: In insgesamt 33 RCT's (Gesamtpatientenzahl 7515) wurde durch das Extrakt von AP eine klinisch wie auch statistisch signifikante klinische Besserung des Allgemeinzustands, der Krankheitsdauer (sick leave), des Hustens, der Schmerzen im Rachen/Hals im Vergleich zu Placebo und anderen Vergleichsrezepturen erreicht. Allerdings war die Qualität der Studien nicht gut [7].

Bei hochfieberhaften Infekten mit makulopapulösen Erythemen und dunkelroter Zunge (in der Terminologie der TCM ,epidemisches Feuer-Toxisches“, duhuo), was im westlichen Kulturkreis Krankheitsbildern wie Scharlach oder auch Menigokokkeninfekten entspricht, wird eine Kombination aus Arzneien aller kühlenden Gruppen gewählt, hier das Beispiel-Rezept Epidemischer klärender und Gift lösender Trank (s. Kasten):

Die Dosen sind hoch und die Anzahl der Mittel ebenso. Hier wird eine akute Krankheit behandelt, das Ziel ist die rasche Besserung innerhalb kurzer Zeit (1-3 Tage): Die Rezeptur wird auch nur maximal 3 Tage verschrieben.

\section{Studienlage}

Der überwiegende Teil der Forschung, der sich mit der Untersuchung antibiotischer Wirkungen der CAT befasst, basiert auf In-

\section{Epidemisches klärender und Gift lösender Trank (Qingwēn bàidú yĩn)}

- Gypsum (shigao) 60-120 g (Dosis abhängig vom Fieber und der Konstitution)

- Anemarrhenae rhizoma (zhimu) $12 \mathrm{~g}$

- Glycyrrhizae radix (gancao) $6 \mathrm{~g}$

- Lophateri herba (danzhuye) $12 \mathrm{~g}$

- Bubali cornu (shuiniujiao) $30 \mathrm{~g}$ zusammen 120 min mit Gypsum kochen

- Rhemania viride radix (shengdi) $12-30 \mathrm{~g}$

- Moutan cortex (mudanpi) $9 \mathrm{~g}$

- Paeonia rubra (chishao) $9 \mathrm{~g}$

- Scrophularia radix (xuanshen) $\mathbf{2 4 g}$

- Scutellariae radix (huangqin) $9 \mathrm{~g}$

- Coptidis rhizoma (huanglian) $6 \mathrm{~g}$

- Forsythiae fructus (lianqiao) $15 \mathrm{~g}$

- Gardeniae fructus (zhizi) $9 \mathrm{~g}$

- Platycodi radix (jiegeng) $9 \mathrm{~g}$

(Angaben g Tagesdosis/Rohdroge, zusammen 30 min abgekocht und dann warm in 3 Dosen über den Tag verteilt eingenommen)

vitro- anstatt auf In-vivo-Studien: Ein aktueller Review liefert Evidenzhinweise für 34 unterschiedliche CAT-Arzneimittel, die Konstituenten enthalten, die bakterielle Ausflusspumpen inhibieren [25]. E. coli zeigt beispielsweise eine Resistenz gegen mehrere Antibiotika. Kombiniert mit Extrakten der Sophora radix (kushen), wurden Isolate der Bakterienstämme als wieder empfänglich für Ciprofloxacin ermittelt.

Wenn Methicillin-resistente Staphylococcus aureus (MRSA) mit einer Kombination von Antibitioka und Berberin behandelt werden (z.B. in Coptis chinensis, Phellodendron amurens), waren die Antibiotika wieder wirksam. Eine mögliche Erklärung könnte die Wiederherstellung der Inhibitionsfunktion durch Berberin sein.

Mehr als 20 Kräuter, die häufig in der chinesischen Medizin verwendet werden, haben einen inhibitorischen Effekt gegen MRSA wie Dendrobenthamia capitata, Elsholtzia rugulosa, Elsholtzia blanda, Geranium strictipes, Polygonum (Zuo).

Die Zufügung von jeweils Emlodin, Berberin, Schizandrin (Bestandteil von Schizandrae fructus (wuweizi) und Baikalin (Hauptbestandteil von Scutellariae radix (huangqin)) führten in vitro ebenso dazu, dass bereits gegen Amoxycyclin und Tetracyclin resistente Helicobacter-pylori-Stämme wieder sensitiv reagierten.
Coptidis rhizoma (huanglian), Mume und Schizandrae fructus (wuweizi) in Kombination zeigten deutliche Wirkung gegen Salmonellen.

Klinische Studien zur Wirksamkeit der CAT liegen zu Harnwegsinfekten vor: Die Arbeitsgruppe um Lilian Lai, Andrew Flower und George Lewith konnten in einem Cochrane Review die Studienlage als positiv bewerten - auch wenn wie meistens weitere Studien notwendig sind [30].

Die wichtigsten Studien und ihre Ergebnisse sind in Tab. 1 zusammengefasst.

\section{Sicherheit}

Die CAT ist eine allopathische Medizin, es können auch hier Nebenwirkungen wie Magen-Darm-Beschwerden und sehr selten Allergien auftreten. In Einzelfällen ist bei bestimmten Arzneidrogen eine Erhöhung der Transaminasen aufgetreten, in sehr seltenen Fällen kann es zu idiosynkratischen Reaktionen der Leber kommen, mit schweren Verläufen (geschätzt 1:10000 bis 100000 je Einnahmejahre).

Insgesamt ist die CAT bei guter Ausbildung und guter Qualität der Arzneien (Bezug aus Apotheken, Überprüfung der Identität, Qualität und Reinheit) eine sichere Methode.

Genauere Informationen beim Centrum für Therapiesicherheit in der TCA: www.ctca.de

\section{Zusammenfassung}

Die chinesische Arzneimitteltherapie kann bei bakteriellen Infekten eine Behandlungsalternative sein. Sie bietet eine Vielzahl von Möglichkeiten, Patienten bei Infekten zu helfen, durch die antibakteriellen, antiviralen und antiinflammatorischen Bestandteile der Arzneidrogen, aber auch durch die Stützung der Konstitution und des Gesamtsystems aus Sicht der TCM. Voraussetzung ist eine genaue westliche und chinesische Diagnose und sichere Kenntnis der Arzneimittel und Rezepturen.

Interessenkonflikt: Der Autor erklärt, dass keine wirtschaftlichen oder persönlichen Verbindungen bestehen.

Online zu finden unter

http://dx.doi.org/10.1055/s-0043-123137 


\section{Literatur}

1 Luxenburger $\mathrm{H}$, Hummelsberger J. Aintibiotikaresistenz im Fokus der EU-Gesundheitspolitik. DZA 2016; 59 (4): 41-43

$\overline{2}$ Pharamacopoeia of the PR of China, Vol I. Beijing: People's Medical Publishing House; 2005

$\overline{3}$ Porkert M. Theoretische Grundlagen der Chinesischen Medizin. Dinkelscherben: Phainon; $1991 / 3$

4 Unschuld PU. Pen Tsao, 2000 Jahre traditionelle pharmazeutische Literatur Chinas. München: Moos; 1973

5 Scheid V, Bensky D, Ellis A, Barolet R. Formulas \& Strageties. Seattle: Eastland Press; 2009/2

$\overline{6}$ https://www.Ifl.bayern.de/ipz/heilpflanzen/059214/index.php

7 Hu XY, Wu RH, Logue Met al. Andrographis paniculata for symptonatic relief of acute respiratory tract infections in adults and children. A systematic review and meta-analysis. PLos One 2017; 12 (8): e0181780

8 Wang CY, Bai XY, Wang CH. Traditional Chinese medicine: a treasured natural resource of anticancer drug research and development. Am J Chin Med 2014; 42: 543-559

$\overline{9}$ Huang J, Su D, Feng Y et al. Antiviral herbs present and future. Infect Disord Drug Targets 2014; 14: 61-73

$\overline{10}$ Andújar I, Ríos JL, Giner RM et al. Pharmacological properties of shikonin - a review of literature since 2002. Planta Medica 2013; 79: 1685-1697

$\overline{11}$ Zhou YX, Xin HL, Rahman K et al. Portulaca oleracea L.: a review of phytochemistry and pharmacological effects. BioMed Research International 2015; 925631.

$\overline{12} \mathrm{He} J \mathrm{M}, \mathrm{Mu} \mathrm{Q}$. The medicinal uses of the genus Mahonia in traditional Chinese medicine: An ethnopharmacological, phytochemical and pharmacological review. J Ethnopharmacol 2015; 175: 668-683

$\overline{13}$ Hao BJ, Wu YH, Wang JG et al. Hepatoprotective and antiviral properties of isochlorogenic acid A from Laggera alata against hepatitis B virus infection. J Ethnopharmacol 2012; 144: 190-194

$\overline{14}$ Wang YS, Wen ZQ, Li BT et al. Ethnobotany, phytochemistry, and pharmacology of the genus Litsea: An update. J Ethnopharmacol 2016; 181: 66-107

$\overline{15}$ Wells TN. Prevention and treatment of viral respiratory infections by traditional Chinese herbs? Malaria Journal 2011; 10 (S1: S3 $\overline{16}$ Tong Y, Jing Y, Zhao D et al. Fluoroquinolone-resistant uncomplicated urinary tract infections, Chinese herbal medicine may provide help. African Journal of Traditional, Complementary and Alternative medicines 2011; 8: 108-114

$\overline{17}$ Zhang XG, Li GX, Zhao SS et al. A review of dihydroartemisinin as another gift from traditional Chinese medicine not only for malaria control but also for schistosomiasis control. Parasitology Res 2014; 113: 1769-1773

$\overline{18}$ Huang YQ, Huang GR, Wu MH et al. Inhibitory effects of emodin, baicalin, schizandrin and berberine on hefA gene: treatment of Helicobacter pylori-induced multidrug resistance. World J Gastroenterol 2015; 21: 4225-4231

$\overline{19}$ Tong Y, Jia S, Han B. Chinese herb-resistant clinical isolates of Escherichia coli. J Altern Complement Med 2013; 19: 387-388

$\overline{20}$ Chang SS, Huang HJ, Chen CY. Two birds with one stone? Possible dual-targeting H1N1 inhibitors from traditional Chinese medicine. PLOS Computational Biology 2011; 7: e1002315

$\overline{21}$ Liu X, Han Y, Peng K et al. Effect of traditional Chinese medicinal herbs on Candida spp. from patients with HIV / AIDS. Adv Dent Res 2011; 23: 56-60

$\overline{22}$ Chu Y, Liu H. Advances of research on anti-HIV agents from traditional Chinese herbs. Adv Dent Res 2011; 23: 67-75

$\overline{23}$ Cui X, Wang Y, Kokudo N et al. Traditional Chinese medicine and related active compounds against hepatitis $B$ virus infection. BioScienceTrends 2010; 4: 39-47

$\overline{24}$ Kwon HA, Kwon Y], Kwon DY et al. Evaluation of antibacterial effects of a combination of Coptidis Rhizoma, Mume Fructus, and Schizandrae Fructus against Salmonella. Int J Food Microbiol 2008; 127: 180-183

$\overline{25}$ Muluye RA, Bian Y, Alemu PN. Anti-inflammatory and antimicrobial effects of heat-clearing Chinese herbs. J Tradit Complement Med 2014; 4: 93-98

$\overline{26}$ Li T, Peng T. Traditional Chinese herbal medicine as a source of molecules with antiviral activity. Antiviral Research 2013; 97: 1-9

$\overline{27}$ Zhang L, Wang G, Hou W et al. Contemporary clinical research of traditional Chinese medicines for chronic hepatitis B in China. Hepatology 2010; 51: 690-698

$\overline{28}$ Wang X, Jia W, Zhao A et al. Anti-influenza agents from plants and traditional Chinese medicine. Phytother Res 2006; 20: 335-341 $\overline{29}$ Yu YY, Wang H, Zhang SW et al. Inhibition of methicillin-resistant Staphylococcus aureus by the compound Qingre granules. Chinese Medical Journal 2010; 123: 1017-1020

$\overline{30}$ Flower A, Wang LQ, Lewith G et al. Chinese herbal medicine for treating recurrent urinary tract infections in women. The Cochrane Database of Systematic Reviews 2015; 6:CD010446.

$\overline{31}$ Chen JK, Chen TT. Chinese Medical Herbology and Pharmacology. Art of Medicine Press; 2003

$\overline{32}$ Huang YQ, Huang GR, Wu MH et al. Inhibitory effects of emodin, baicalin, schizandrin and berberine on hefA gene: treatment of Helicobacter pylori-induced multidrug resistance. World ] Gastroenterol 2015; 21 (14): 4225-423

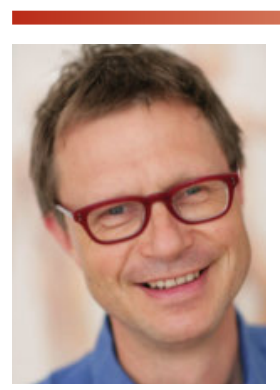

\section{Dr. Josef Hummelsberger}

Vize-Präsident der SMS (Societas medicinae sinensis)

Hackenstr. 7

80331 München

praxis@hummelsberger.net

www.hummelsberger.net

Studium der Medizin in Göttingen und München, Facharztausbildung zum Internisten. Seit 1982 Ausbildung in Akupunktur bei verschiedenen Fachgesellschaften. Seit 2005 in eigener Praxis mit dem Schwerpunkt Akupunktur \& Chinesische Medizin tätig. Seit 1997 Dozent und Gastdozent für Akupunktur und Chinesische Medizin bei ärztlichen Fachgesellschaften, Akademien und Universitäten (SMS, DGFAN, DÄGFA, EIOM, Ärztekammer Westfalen-Lippe, Donau-Universität Krems). 


\section{Studies}

\section{Aim}

Assessment of the effects of Chinese herbs on the uncomplicated urinary tract infections (UTIs) in women caused by fluoroquinolone-resistant strains.

Investigation of the inhibitory effects of emodin, baicalin, etc. on the hefA gene of multidrug resistance (MDR) in Helicobacter pylori (H. pylori).

Animal testing: The antibacterial potential of a preparation of medicinal herbs for the treatment of salmonellosis was evaluated.

This review has listed 11 heat-clearing Chinese herbs (HCCHs) including Scutellaria baicalensis (Huáng Qín), Coptis chinensis ( Huáng Lián), Flos Lonicerae ( Jīn Yín Hūa), Forsythia suspensa (Lián Qiào), Isatidis Folium (Dà Qīn Yè), Radix Isatidis (Băn Lán Gēn), Viola yedoensis ( Zǐ Huā Dì Dīn), Pulsatilla Radix ( Bái Tóu Wēn), Andrographis paniculata ( Chuān Xīn Lián), Houttuynia cordata (Yú Xīng Cǎo), and Patrinia Herba ( Bài Jiàn Căo), which have anti-inflammatory and antimicrobial effects, and has described their effects through different mechanisms of action and multiple targets.

Review: Search of Cochrane Kidney and Transplant's Specialised Register to 7 May 2015 through contact with the Trials Search Co-ordinator, using search terms relevant to this review. We also searched AMED, CINAHL and the Chinese language electronic databases Chinese BioMedical Literature Database (CBM), China Network on Knowledge Infrastructure (CNKI), VIP and Wan Fang Databases to July 2014.

Chinese herbal medicine (CHM) for recurrent urinary tract infections
Treatment

The patients were orally administrated Chinese herbal concoction for ten days.

A total of four MDR H. pylori strains were screened. Treatment with emodin, baicalin, schizandrin and berberine significantly decreased the MICs of amoxicillin and tetracycline against some strains, decreased by 1 to 2 times, but did not significantly change the MICs of clarithromycin, levofloxacin, and metronidazole against MDR strains.

The histopathological observations of the NP532 treated animals did not show any of the clinical signs and rarely showed histological damage associated with the disease. On the other hand, the untreated controls showed the clinical signs, e.g. congestion and necrotic changes in the liver, kidney, and spleen.

Their ability to affect multiple target signaling pathways and their potential mechanisms of action contributing to their anti-inflammatory and antimicrobial activity may be related to their action of removing heat and counteracting toxicity.

However, the small number and poor quality of the included studies meant that it was not possible to formulate robust conclusions on the use of CHM for recurrent UTI in women either alone or as an adjunct to antibiotics.

Seven RCTs that involved a total of 542 women; of these, five recruited post-menopausal women (aged from 56 to 70 years) (422 women).

All studies were assessed to be at high risk of bias.

Analysis of three studies involving 282 women that looked at CHM versus antibiotics suggested that CHM had a higher rate of effectiveness for acute UTI (RR 1.21, 95\% Cl: 1.11 - 1.33) and reduced recurrent UTI rates (RR $0.28,95 \% \mathrm{Cl}: 0.09-0.82$ ). Analysis of two studies involving 120 women that compared CHM plus antibiotics versus antibiotics alone found the combined intervention had a higher rate of effectiveness for acute UTI (RR 1.24, 95\% Cl: 1.04 $1.47)$ and resulted in lower rates of recurrent infection six months after the study (RR $0.53,95 \% \mathrm{Cl}: 0.35-0.80$ ).

One study comparing different CHM treatments found Er Xian Tang was more effective in treating acute infection in post-menopausal women than San Jin Pian ( 80 women: RR 1.28, 95\% Cl: $1.03-1.57$ ). Analysis showed that active CHM treatments specifically formulated for recurrent UTI were more effective in reducing infection incidence than generic CHM treatments that were more commonly used for acute UTI (RR 0.40, 95\% CI: 0.21 - 0.77).
Chinese herbal therapy may be an acceptable alternative for the treatment of uncomplicated UTIs caused by fluoroquinolone-resistant uropathogens.

Emodin, baicalin, schizandrin and berberine significantly decreased the MICs of amoxicillin and tetracycline against some $\mathrm{H}$. pylori strains, possibly by mechanisms associated with decreasing hefA mRNA expression.

NP532 might be an effective treatment for salmonellosis.

A large number of studies have reported on the anti-inflammatory and antimicrobial effects of the traditional Chinese herbs.

CHM treatments specifically formulated for recurrent UTI may be more effective than herbal treatments designed to treat acute UTI.

CHM as an independent intervention o in conjunction with antibiotics may be beneficial for treating recurrent UTIs during the acute phase of infection and may reduce the recurrent UTI incidence for at least six months post-treatment

Tab. 1 Ausgewählte Studien zur CAT. 